Original Paper

\title{
Kinetic Study of Glucose Production from Cellobiose through Hydrolysis with Solid Acid Catalyst
}

\author{
Makoto KITANO *1, Kenji SATO *1, Kentaro NARIAI ${ }^{* 1}$, Norimitsu KANEKO*1, and Michikazu HARA*2*3 \\ (Received January 23, 2012)
}

\author{
カーボン系固体酸触媒反応によるセロビオースからのグルコース加水分解反応の速度論研究 \\ 北野 誠*1, 佐藤健治*1，成相健太郎*1，金子典充*1，原 亨和*2*3
}

\begin{abstract}
Kinetic study of glucose production from cellobiose through hydrolysis has been performed to compare reaction characteristics by using reaction models with $\beta$-glucosidase (Trichoderma reesei) and with graphenebased amorphous solid acid catalyst (SAC). The decrease of cellobiose concentration through hydrolysis with $\beta$-glucosidase is inhibited by present glucose as reported, resulting in unreacted cellobiose remained for a long time. In contrast cellobiose concentration decreased with SAC obeying 1st reaction rate model, showing relatively rapid reaction rate without such inhibition observed in hydrolysis with $\beta$-glucosidase. By using the plug flow reactor with a SAC packing column, an attempt of catalytic aging experiment was carried out about over 4,000 h, succeeding in construction of the 1st order reaction rate model.
\end{abstract}

\section{Key Words}

Kinetics, Graphene-based amorphous solid acid catalyst, Hydrolysis, Glucose, Cellobiose

\section{1. 緒 言}

リグノセルロースからグルコースを生成する糖化反応プロ セスは，加水分解反応による複数の低分子化反応から構成さ れており，処理方法として熱水や酸・アルカリ，拈よび酵素 を用いた加水分解方法などが提示されている。この糖化反応 プロセスの主要な反応の一つとして，七ロビオース (G2) か らグルコース $(\mathrm{G} 1)$ を生成するセロビオース糖化反応があり, この反応を担う酵素加水分解反応は, 生体触媒である酵素 $\beta$ グルコシダーゼ（BGL）によって行われる。BGLによる加水 分解反応は，セロビオースや短い鎖（セロオリゴ糖）の末端 からグルコースを生成するエキソ型の反応である。リグノセ ルロースの加水分解にはBGL以外にも，多種類の酵素 (セル ラーゼ）を必要とし，例えば糸状菌Trichoderma reeseiでは総 計18種類存在して糖化反応プロセスを協働して加水分解をし

$* 1$ IHI Corporation Shin-Nakahara 1, Isogo-ku, Yokohama-shi, Kanagawa 235-8501, Japan

* 2 Kanagawa Academy of Science and Technology 3-1-2 Sakado, Takatsu-ku, Kawasaki-shi, Kanagawa 213-0012, Japan

* 3 Materials \& Structures Laboratory,

Tokyo Institute of Technology

4259 Nagatsuta, Midori-ku, Yokohama-shi, Kanagawa 229-8503, Japan
ていることが分かっている11。現在，市販セルラーゼ剤の中で 最もバイオマスの糖化効率が高いのはこの Trichoderma reesei 由来のセルラーゼであるため, 活性向上の観点から, このBGL 活性についても改善研究が行われている2３)。

一方, 北野ら ${ }^{4)}$ は化学触媒であるカーボン系固体酸触媒 (SAC) を用いて, セロオリゴ糖の加水分解反応を行い, 反応

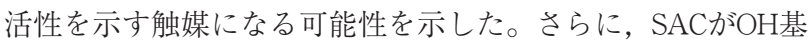
や $\mathrm{COOH}$ 基によって強酸点である $\mathrm{SO}_{3} \mathrm{H}$ 基の近傍にセロオリ ゴ糖を吸着できるためセロオリゴ糖の加水分解に非常に高い 活性を示すことを明らかにした ${ }^{5)}$ 。北野ら ${ }^{6)}$ は, 固体酸触媒 を用いたセロビオースからのグルコース生成反応速度モデル を提示することで，エンジニアリング利用方法を示した。成 相ら 7) は, ろ紙の $270^{\circ} \mathrm{C}$ 水熱処理液を原料として固体酸触媒 処理を行い，グルコースの生成とオリゴ糖からグルコース回

$* 1 \quad$ (株) IHI 干 235-8501 神奈川県横浜市磯子区新中原 1

*2 神奈川科学技術アカデミー テ 213-0012 神奈川県川崎市高津区坂戸 3-1-2

*3 東京工業大学 干 229-8503＼cjkstart神奈川県横浜市緑区長津田 4259 
収が可能であることを示した。このようにSACを用いること で酵素BGLに代替できるセロビオース加水分解機能があるこ とが分かり，化学触媒であることから生体触媒（BGL）の有 する欠点を解消する可能性があるため, その実用化に期待が 集まっている。

本論文では，七ロビオースからグルコースを生成するセロ ビオース加水分解反応速度について, 反応速度モデルを用い てBGLと SACによる比較を行い, SACによる加水分解反応 の特徴を示すことを目的とした。さらにSACを用いた流通式 固体触媒反応の約4,000 hにわたる経時性能試験を行い触媒性 能の有効性を実証すること，扔よび種々の反応条件下におけ る試験結果と比較することでセロビース糖化触媒としての $\mathrm{SAC}$ 反応速度モデルを試験検証することも目的とした。

\section{2. 実 験}

\section{1 カーボン系固体酸触媒（SAC）}

この試験に用いたSACの製造方法は北野4)らの方法と同じ で，この研究機関より入手した。その物性は，元素組成 $\mathrm{CH}_{0.64} \mathrm{O}_{0.49} \mathrm{~S}_{0.03}$ で，酸密度: $1.5 \mathrm{mmol} / \mathrm{g}$, 最大酸性度:-8 - $11 \mathrm{Ho}$, 比表面積: $2 \mathrm{~m}^{2} / \mathrm{g}$ であった。この SAC は Fig. 1 に示すとおり 数 $\mu \mathrm{m}$ から約 $200 \mu \mathrm{m}$ の粒子径分布を示し, そのメディアン 径は $67 \mu \mathrm{m}$ であった。

\section{2 カーボン系固体酸触媒 (SAC) 反応試験}

カーボン系固体酸触媒 (SAC) バッチ試験容器は $100 \mathrm{~mL}$ 容 の円筒形ガラス製容器で, 試験容器内部に擋拌用パドルを挿 入し $400 \mathrm{rpm}$ で連続摚拌しながら，試験容器内部温度を最高 $100^{\circ} \mathrm{C}$ に維持するためオイルバスに浸漬することで外部加温し てバッチ処理を行った。試験容器上部に蒸気をドレン化して 試験装置に還流するコイル冷却装置を用いて，蒸気漏れを防 止しながら実験を実施した。種々の濃度のセロビオース水溶 液 $20 \mathrm{~mL}$ と SAC を混合して規定濃度の SAC 濃度 $50 \mathrm{~g} / \mathrm{L}$ にな るようにした。この試験装置を用いたSAC反応時間直後， 1 ， $2 ， 3 ， 4 ， 5 ， 6 \mathrm{~h}$ 後にサンプリングした。

カーボン系固体酸触媒 (SAC) の連続供給条件下でグルコー スに加水分解する長期触媒活性を試験するために，円筒形の 反応管 (ステンレス製, 充填容量 $11 \mathrm{~mL}$, 内径 $7.5 \mathrm{~mm} \times$ 充填 長 $25 \mathrm{~mm}$ ）に，固定層として粉末状のSACを $5.3 \mathrm{~g}$ 充填した。 この反応管を HPLC 用オーブン中に配置して反応管温度を $100^{\circ} \mathrm{C}$ に維持した。この反応管に $10 \mathrm{~g} / \mathrm{L}$ 濃度のセロビオース 溶液を流量 $0.1 \mathrm{~mL} / \mathrm{min}$ （水理学的滞留時間 $: \mathrm{HRT}=1.83 \mathrm{~h}$ ) で送液した。実験開始後, セロビオースがグルコースに加水 分解する状況をモニターするため, 数時間毎にSAC流通式反 応試験装置入口と出口において液サンプリングを行った。セ ロビオースとグルコースの分析は HPLCによって行った。こ の状態で連続のSAC流通式反応試験を開始し, 以降はSACの 交換と補充を行うことなく，期間中の液分析を元にSACによ る加水分解反応の状況を約 $4000 \mathrm{~h}$ に渡りモニターした。

ペレット形状（円柱断面直径 $1 \mathrm{~mm} \times$ 高さ $4 \mathrm{~mm}$ ) に成型 したSACを使って流通式反応モデルを検証するため，スケー ルアップ円筒形の反応管（ステンレス製，充填容量 $200 \mathrm{~mL}$ ： 内径 $30 \mathrm{~mm} \times$ 充填長 $300 \mathrm{~mm}$ ) に，固定層として SACを 100 g充填した。この装置図をFig. 2に示す。この反応管を外部電 気ヒータで加熱して反応管温度を $50,70,90^{\circ} \mathrm{C}$ に維持した。こ の反応管に，七ロビオース溶液濃度 50, 100, $120 \mathrm{~g} / \mathrm{L}$ の各濃 度（HRT を設定して）で送液した。Table 1 にSAC 流通反応 器の全反応試験条件を記す。

グルコース，セロビオースの分析は，液体クロマトグラフ 装置 (LC-2000Plus, Jasco) にイオン交換カラム (Amenex HPX87H, Bio-Rad）を用いた装置を用いた。

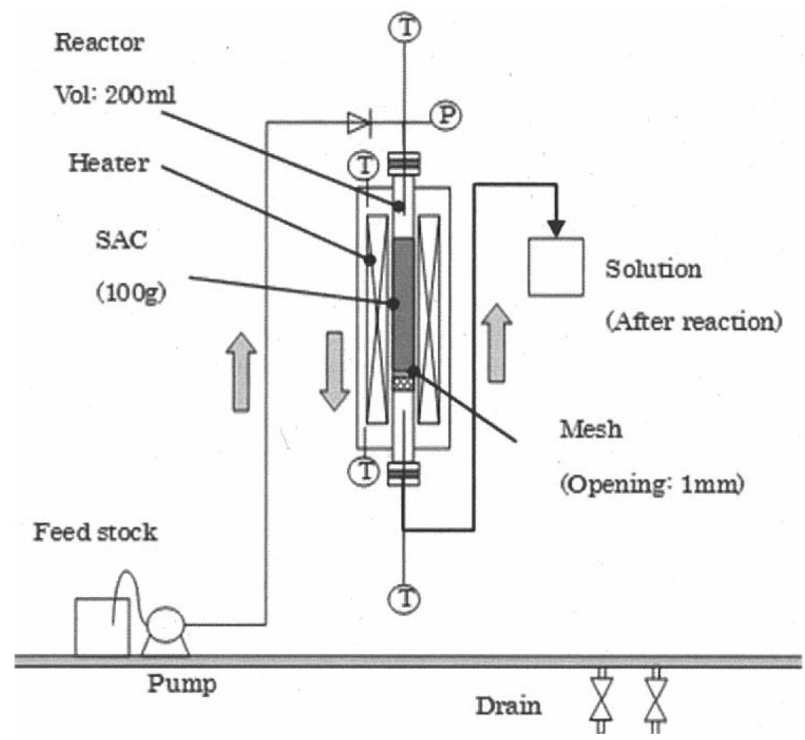

Fig. 2 Process flow diagram of SAC plug flow reactor

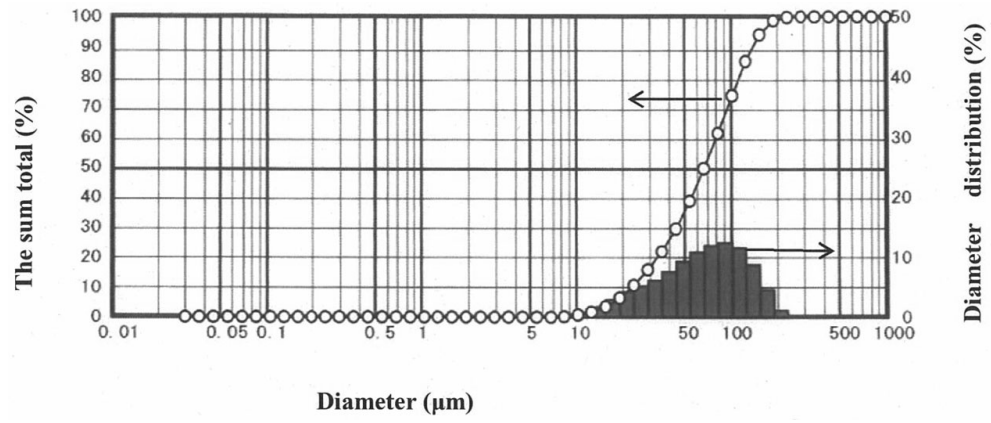

Fig.1 Profile of SAC particle diameter 
Table 1 Experimental conditions of PFR-SAC reaction with cellobiose

\begin{tabular}{cccc}
\hline \multicolumn{4}{c}{ PFR experimental conditions } \\
\hline $\begin{array}{c}\text { Temperature } \\
{ }^{\circ} \mathrm{C}\end{array}$ & $\begin{array}{c}\text { Flow rate } \\
\mathrm{mL} / \mathrm{min}\end{array}$ & $\begin{array}{c}\theta: \text { HRT } \\
\mathrm{h}\end{array}$ & $\begin{array}{c}\mathrm{Cc0} \\
\mathrm{g} / \mathrm{L}\end{array}$ \\
\hline 50 & 30.9 & 1 & 50 \\
50 & 15.5 & 2 & 100 \\
70 & 15.5 & 2 & 120 \\
70 & 7.7 & 4 & 50 \\
90 & 15.5 & 2 & 50 \\
& 7.7 & 4 & 100 \\
\hline
\end{tabular}

Cco: Inlet cellobiose concentration

HRT: Hydroulic retention time

SAC packing: $100 \mathrm{~g}$ in the column $(0.20 \mathrm{~L}: \phi 30 \times 300 \mathrm{~mm})$

\section{3. 結果と考察}

3.1 セロビオースからのグルコース生成の加水分解反応速 度モデル

セロビオースからグルコースに加水分解を行う $\beta$-グルコシ

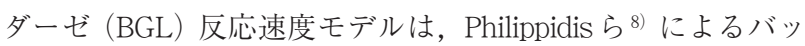
チ同時糖化発酵試験からの結果を用いた。彼らはTrichoderma reesei 由来の BGL活性を調べ, BGL添加量 $25 \mathrm{IU} / \mathrm{g}$-cellbioseに おいて反応速度式中の $\mu_{\max }=14.22 \mathrm{~g} / \mathrm{L} / \mathrm{h}$ を求め, $10 \mathrm{~g} / \mathrm{L}$ の セロビオースに対してBGLを 25 IU/g-cellobiose添加した試験 によってミカリエス定数: $K_{\mathrm{m}}=10.56 \mathrm{~g} / \mathrm{L}$ ，さらにグルコー ス濃度を 0 から $20 \mathrm{~g} / \mathrm{L}$ に変えることで阻害定数：K $K_{2 \mathrm{G}}=0.62$ g/Lを決定した。彼らの研究によればセロビオース濃度を 2 か ら $70 \mathrm{~g} / \mathrm{L} に$ 変えて反応初期の加水分解速度を調べた試験にお いて反応速度式上のセロビオース濃度阻害を確認できなかっ たと報告している。そのため，本研究ではセロビオース濃度 阻害項： $C_{c} / K_{2 c}$ に 0 を代入した下記のセロビオオース加水分 解反応速度の計算式を用いた。

$$
\mu=\mu \max \frac{C_{C}}{K_{m}\left(1+\frac{C_{G}}{K_{2 G}}\right)+C_{C}\left(1+\frac{C_{C}}{K_{2 C}}\right)}
$$

一方，カーボン系固体酸触媒 (SAC) において北野ら ${ }^{6)}$ は, セロビオースからグルコースの生成反応と消失反応が同時に 起こる次の反応経路をもとに，バッチ反応試験結果に基づい て速度モデルを検討した。ここでは各反応の速度定数を $k_{G D}$ と kGd としている。

Cellobiose $\stackrel{k G D}{\longrightarrow}$ Glucose $\stackrel{k G d}{\longrightarrow}$ Depmposed product (2)

北野らの報告 ${ }^{6)}$ では $\mathrm{SAC}$ 反応 $\left(100^{\circ} \mathrm{C}\right)$ での $k_{G D}{ }^{*}$ 值（反応 速度定数 $k_{G D}$ を固体酸触媒濃度 $A$ で割ったもの) として，その 平均值が $2.6 \times 10^{-3} \mathrm{~L} /(\mathrm{g} \cdot \mathrm{h})$ であったのに対してグルコース分 解速度定数の平均值 $\mathrm{kGd}^{*}$ が $7.7 \times 10^{-7} \mathrm{~L} /(\mathrm{g} \cdot \mathrm{h})$ であったため, グルコース分解の反応速度は実質無視できるとした。そのた めグルコース生成の反応速度が式(3)のようにセロビオース濃 度 $C_{c}$ 対して一次反応式で記述して反応消失した 1 モルのセロ ビオース（分子量 342.3）から 2 モルのグルコース（分子量 180.1）が生成するとして，反応時間 $t$ におけるグルコース濃
度 $C_{G}$ は式(4)のように初期セロビオース濃度 $C_{C 0}$ とグルコー 又生成反応速度定数 $k_{G P}$ を用いて記述できる。

$$
\begin{aligned}
& \frac{d C_{G}}{d t}=\frac{2 \times 180.1}{242.3} k_{G D} C_{C}=\frac{2 \times 180.1}{242.3} k_{G D}\left(C_{C 0}-\frac{242.3}{2 \times 180.1} C_{G}\right) \\
& =1.053 \mathrm{k}_{G D}\left(C_{C 0}-0.95 C_{G}\right) \\
& C_{G}=1.053 C_{C 0}\left\{1-\exp \left(-k_{G p} t\right)\right\}
\end{aligned}
$$

反応速度定数 $k_{G P}$ は $\mathrm{SAC}$ の濃度に依存することが考えられ るため, SAC 濃度 Aが一次に反応速度に影響を与えるとして $k_{G D}$ を $A$ で割ったものを $k_{G D}{ }^{*}$ とすれば $\mathrm{SAC}$ 濃度とは独立し て扱うことができる。 $k_{G D}{ }^{*}$ 用いれば式(4)は式(5)の表現とな り，数值を代入すれば式(6)となる。

$$
\begin{aligned}
& C_{G}=1.053 C_{c 0}\left\{1-\exp \left(-k_{G D}{ }^{*} A t\right)\right\} \\
& C_{G}=1.053 C_{C 0}\left\{1-\exp \left(-2.6 \times 10^{-3} A t\right)\right\}
\end{aligned}
$$

3.2 バッチ処理における $\beta$-グルコシダーゼ (BGL) とカー ボン系固体酸触媒（SAC）の加水分解反応速度

セロビオース初期濃度 $50 \mathrm{~g} / \mathrm{L}$ のバッチ処理条件で，BGLと $\mathrm{SAC}$ によって糖化する加水分解反応の計算を上記の反応速度 モデルを用いて行なった。BGLの場合に Philippidis ら ${ }^{8)}$ が得 た速度定数と BGL を 25 と $40 \mathrm{IU} / \mathrm{g}$-cellobiose 添加した試験に よる最高加水分解速度を元にして，それぞれのセロビオース の減少とグルコースの生成の時間経過シミュレーション計算 結果を Fig. 3 に示す。Fig. 3 には, Philippidis らの試験で検証 されていないが100 IU/g-cellobioseでの加水分解反応結果も併 せて示す。100 IU/g-cellobiose を添加した場合でも BGL では セロビオース $2 \mathrm{~g} / \mathrm{L}$ 以下 (96\%分解) まで加水分解するのに約 40 h を要したことが分かる。

同じくセロビオース初期濃度 $50 \mathrm{~g} / \mathrm{L}$ のバッチ処理条件にお いて, $\mathrm{SAC} の$ 場合の反応温度 $100^{\circ} \mathrm{C}, \mathrm{SAC}$ 濃度 $150 \mathrm{~g} / \mathrm{L}$ にお

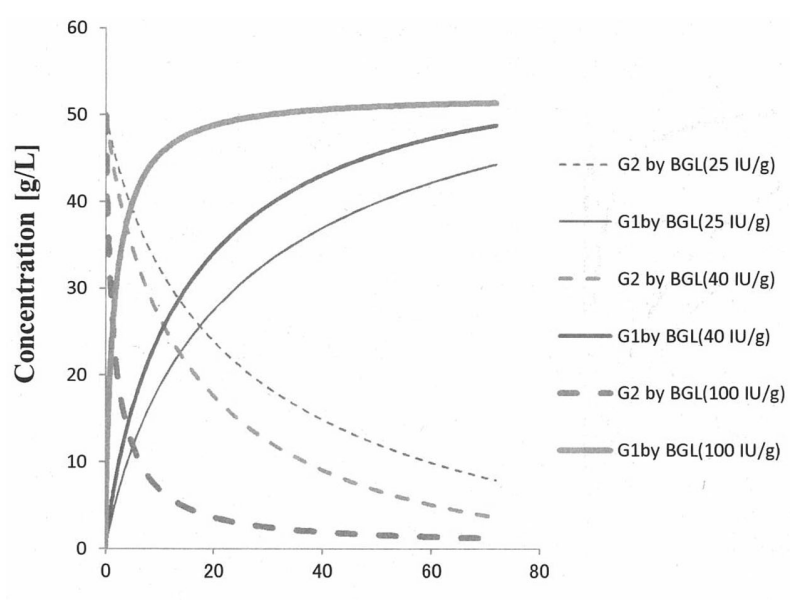

Reaction time $[\mathrm{h}]$

Initial cellobiose concentration, $50 \mathrm{~g} / \mathrm{L}$

BGL: $25 \mathrm{IU} / \mathrm{g}$-cellobiose; $\mu \max , 14.22 \mathrm{~g} / \mathrm{L} ; \mathrm{Km}, 10.56 \mathrm{~g} / \mathrm{L} ; \mathrm{K} 2 \mathrm{G}, 0.62 \mathrm{~g} / \mathrm{L}$ $40 \mathrm{IU} / \mathrm{g}$-cellobiose; $\mu \max , 22.75 \mathrm{~g} / \mathrm{L} ; \mathrm{Km}, 10.56 \mathrm{~g} / \mathrm{L} ; \mathrm{K} 2 \mathrm{G}, 0.62 \mathrm{~g} / \mathrm{L}$ $100 \mathrm{IU} / \mathrm{g}$-cellobiose; $\mu \max , 56.88 \mathrm{~g} / \mathrm{L} ; \mathrm{Km}, 10.56 \mathrm{~g} / \mathrm{L} ; \mathrm{K} 2 \mathrm{G}, 0.62 \mathrm{~g} / \mathrm{L}$

Reaction temperature, $50^{\circ} \mathrm{C}$

Fig. 3 Calculation result of hydrolysis from cellobiose (G2) to glucose (G1) at three $\beta$-glucosidase (BGL) concentrations of 25,40 and $100 \mathrm{IU} / \mathrm{g}$ 
ける結果を Fig. 4 に示すが, 試験結果と計算值がほぼ一致し ていることが分かる。その計算值において，加水分解反応時 間 $20 \mathrm{~h}$ においてセロビオース $0.1 \mathrm{~g} / \mathrm{L}$ 以下（99\%分解）まで 加水分解できた。SACによるセロビオース加水分解パターン は, BGLの場合と比較するとBGL添加量で100 IU/g-cellobiose での状況に相当することが理解できる。

両触媒（BGL と SAC）のセロビオース初期濃度 $10 \mathrm{~g} / \mathrm{L}$ 条件 での反応速度比較を Fig. 5 に示す。両触媒とも反応速度は時

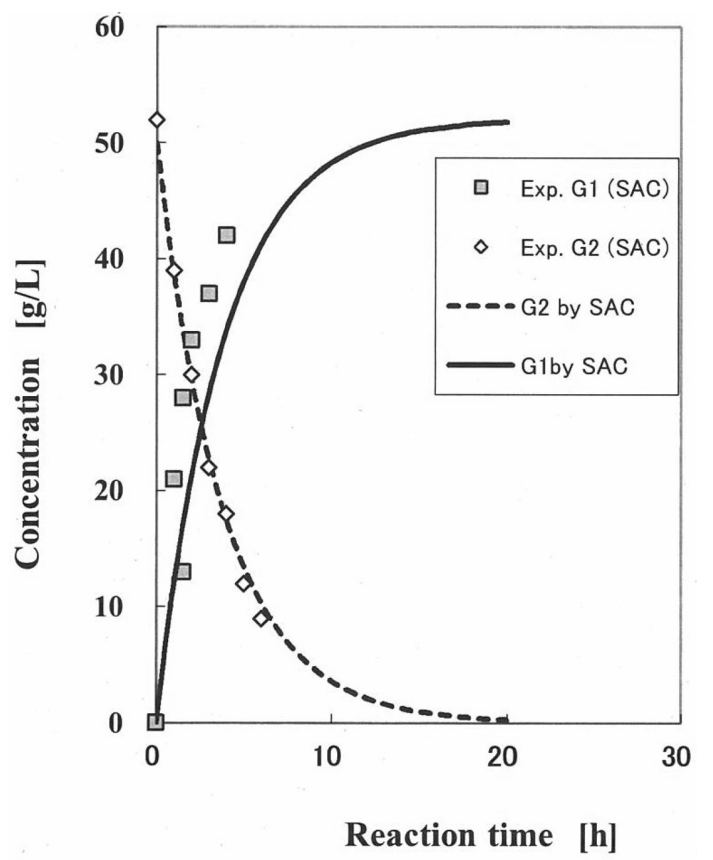

Fig. 4 Glucose (G1) production from cellobiose (G2) with SAC

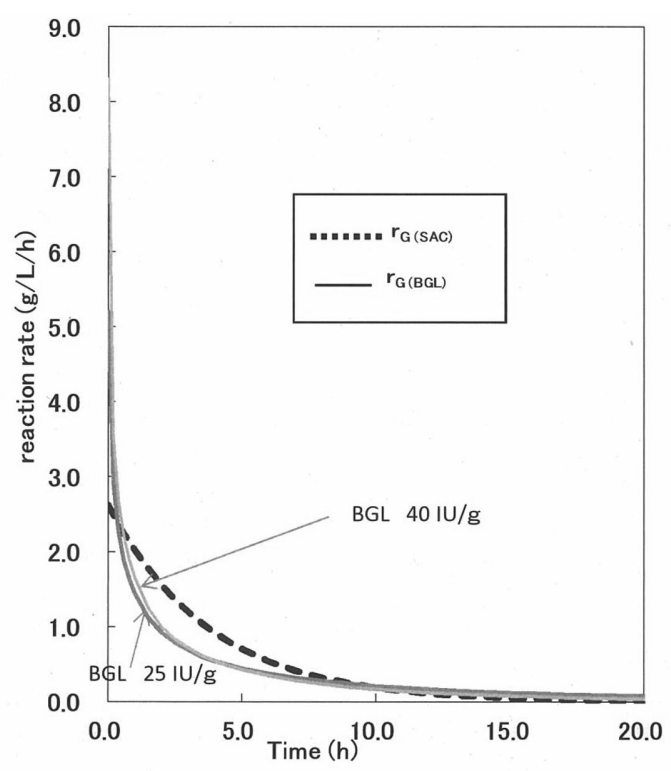

Initial cellobiose concentration, $10 \mathrm{~g} / \mathrm{L}$

SAC concentration, $150 \mathrm{~g} / \mathrm{L}$; Reaction temperature, $100^{\circ} \mathrm{C}$;

BGL: 25 IU/g-cellobiose; $\mu$ max, 14.22 g/L; Km, 10.56 g/L; K2G, 0.62 g/L

: $40 \mathrm{IU} / \mathrm{g}$-cellobiose; $\mu$ max, $14.22 \mathrm{~g} / \mathrm{L} ; \mathrm{Km}, 10.56 \mathrm{~g} / \mathrm{L} ; \mathrm{K} 2 \mathrm{G}, 0.62 \mathrm{~g} / \mathrm{L}$

Fig. 5 Comparison of hydrolysis reaction rate between $\mathrm{SAC}$ and $\beta$-glucosidase (BGL)
間経過に伴い低下しているが，その機構は大きく異なる。つ まりBGLは反応開始直後にグルコース濃度増加によって反応 速度は急激に低下し，5 h 後には初期活性の1/10 以下にまで 反応速度が低下した。この評価に用いたTrichoderma reese $i$ 由 来 BGL の反応速度式 (1) 中の阻害定数: $K_{2 G}=0.62 \mathrm{~g} / \mathrm{L}$ が示す ように，セロビオース加水分解反応速度の向上には Trichoderma reese $i$ 由来BGLのグルコース濃度阻害の緩和が課題であ ることが理解できる。

一方 SAC はセロビース濃度の低下に伴い反応速度は低下 し，セロビオースの消失によって反応速度はゼロに漸近して 加水分解は完結する。SAC の加水分解反応速度向上のために は, 高い反応温度で加水分解をおこなうことと, 反応液中に存 在させる SAC 濃度を向上させることが挙げられる。北野ら ${ }^{6)}$ は， 60 から $100^{\circ} \mathrm{C}$ の SAC による反応モデルの $k_{G p}{ }^{*}$ に与える温 度影響としてアーレニウス式の関係を得ることで大気圧下で は $100^{\circ} \mathrm{C}$ が SAC 反応速度の最大值を与える温度であるとし， SAC 濃度 : 100，150，200 g-SAC/L での反応速度モデル計算 值が試験結果と一致していることを示している。

\section{3 カーボン系固体酸触媒（SAC）による加水分解過程}

$\mathrm{SAC}$ 粒子周りの境膜中の移動速度式は, 粒子単位外表面積 当たりの質量流束 $W_{A}$ ，単位体積当たりのSAC外表面積をaで 表すと次式となる。

$$
a W_{A}=a k_{L} C_{C}
$$

代入する数值として境膜物質移動係数 $\mathrm{kL}_{L}$ が $10^{-4} \mathrm{~m} / \mathrm{s}$ のオー ダであり,たとえば50 g/Lのセロビオースが境膜外部に存在す る場合には, 直径 $1 \mathrm{~mm}$ の SAC 粒子が $150 \mathrm{~g} / \mathrm{L}$ の濃度で浮遊す る単位体積 $\left(1 \mathrm{~m}^{3}\right)$ 当たりの $\mathrm{SAC}$ 粒子の外表面積が約 $100 \mathrm{~m}^{2}$ / $\mathrm{m}^{3}$ となるため, $a=100 \mathrm{~m}^{2} / \mathrm{m}^{3}, \mathrm{k}_{L}=10^{-4} \mathrm{~m} / \mathrm{s}=0.36 \mathrm{~m} / \mathrm{h}$, $\mathrm{CC}=50 \mathrm{~g} / \mathrm{L}$ を代入すると,$a W_{A}=500 \mathrm{~g} /\left(\mathrm{m}^{3} \mathrm{~s}\right)=1800 \mathrm{~g} /$ $(\mathrm{L} / \mathrm{h})$ となる。今回の試験で用いた SAC粒子の粒子径分布は 平均メディアン径 $67 \mu \mathrm{m}$ で最大粒子径が約 $200 \mu \mathrm{m}$ であった

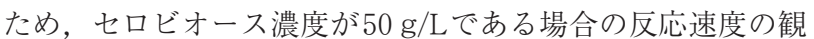
測值が約 $13 \mathrm{~g} / \mathrm{L} / \mathrm{h}$ であったことと対比してSAC粒子廻りの境 膜物質移動は律速段階ではないと推察できるため, この過程 は除いて考えて良い。また，デー夕を示していないが，結果 的に粒子径が異なった (メディアン径が数十から百 $\mu \mathrm{m}$ ) SAC 粒子を用いた反応速度の測定試験において本反応速度定数が 粒子径に関係なくほぼ一定の值であったと判断できたことか ら，細孔内拡散速度が影響していない状況で得られた定数と 推察した。

さて，SAC粒子のサイズが大きくなりすぎると SAC粒子の 細孔内拡散速度支配が㧍こり, 粒子内濃度分布が発生し 1 個 の触媒粒子の反応速度は減少するためグルコース収率の低下 に帰結する。触媒外表面から内部までセロビオース濃度が一 定である最大反応速度に対して, 粒子内に濃度分布が発生し て反応速度が低下した場合の反応速度比は，触媒有効係数 $\eta$ で表される。 $k_{G D}{ }^{*}$ が粒子内物質移動の影響のない条件下の值で あれば，一次反応に㧍ける Thiele数申は次式によって算出さ れる9)。 
$\phi=\frac{1}{6} d_{p} \sqrt{\frac{k_{G p}{ }^{*} \rho}{d_{e A}}}$

ここで式(8)において $D_{\mathrm{eA}}$ は有効拡散係数で，セロビースの 水中での拡散係数 $D=1 \times 10^{-9} \mathrm{~m}^{2} / \mathrm{s}$ を元に, SACの空隙率 $\varepsilon$ として 0.5 と細孔屈曲係数 $\tau$ を 2 して, $D_{\mathrm{eA}}=(\varepsilon / \tau) \times D$ の関係から $D_{\mathrm{eA}}$ を算出する。反応による消失項 $k_{G D} * \rho$ は SAC 触媒の反応器設計值である $k_{G D}{ }^{*}=2.6 \times 10^{-3} \mathrm{~L} /(\mathrm{g} \cdot \mathrm{h})$ と, 水 中におけるSAC触媒 1 個が占める空間の見かけ密度 $\rho=1200$ g/L を掛け合わせして算出する。以上の值から $\phi$ を導出する

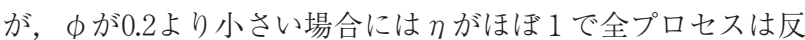

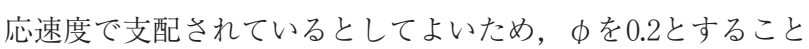
で反応速度が支配できる最大限界粒子径（直径）： $d_{p} \max$ は $0.645 \mathrm{~mm}$ と求まる。例えば拡散速度が反応速度と同様に加水

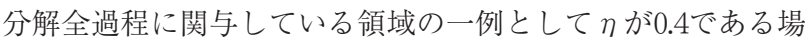
合には $d_{p}$ は約 $6.45 \mathrm{~mm}$ と求まる。上述の方法を用いて, 反応 速度と物質移動速度の観点から SAC粒子の最適粒子径の設計 を行うことができる。

\section{4 流通反応器を用いたカーボン系固体酸触媒 (SAC) 触 媒の長期性能検証}

BGLが生体触媒の特長を有することとは異なり，SACは化 学反応速度で表現できの加水分解特性を示すことが分かった。 3.2 項で記述したように SAC の加水分解反応速度向上のため には，反応液中に存在させるSAC濃度を向上させることが必 要となる。完全混合槽で混合する上で，擋拌混合性から決ま る上限 SAC 濃度である約 $200 \mathrm{~g}-\mathrm{SAC} / \mathrm{L}$ を超えて反応リアク ターを設計するためにはSACを固定層で使用することが必要 となる。そこでSACを流通反応器固定層に充填し, 高密度 $(485$ g-SAC/L) 充填して SACによるセロビオース加水分解触媒性 能を試験検証した。セロビオースからグルコース生成反応の SAC 触媒性能を経時グルコース濃度で表した結果を Fig. 6 に 示す。SACの触媒性能は $4000 \mathrm{~h} の$ 経過時間にわたり，本試験 条件である入口セロビオース濃度 $C_{C 0}=10 \mathrm{~g} / \mathrm{L}$ および $\mathrm{SAC}$ 触
媒充填部の水理学的滞留時間 (以下, HRT) $\theta=1.83 \mathrm{~h} に お ~$ いて，グルコース収率 $Y_{G}=30 \%$ 以上を維持した ${ }^{6)}$ 。

この期間でグルコース収率が徐々に低下するのはSAC触媒 性能の失活が原因であると考えられ，この影響をSACの失活 項 (定数) として $k_{D A}$ を用いて反応速度式を表現したのが式 (9) （10）である。

$$
\begin{aligned}
C_{G} & =1.053 C_{C O}\left[1-\exp \left(-k_{G D} \theta \eta_{0}\right)\right. \\
k_{G D} & =k_{G D} * \exp \left(-k_{D A} t\right) \\
Y_{G} & =\frac{C_{G}}{C_{C 0}}
\end{aligned}
$$

ここではSAC流通反応器のグルコース生成反応速度係数を 同じく $k_{G D}{ }^{*}$ として $2.6 \times 10^{-3} \mathrm{~L} /(\mathrm{g} \cdot \mathrm{h}), \mathrm{SAC}$ 失活速度係数 $k_{D A}$ として $1.4 \times 10^{-4} \mathrm{~h}^{-1}$ ，フィッティング係数を $\eta_{0}$ として試験結 果からフィッティングして決まる $\eta_{0}$ として 0.29 を代入する。 3.3項の検討から, 今回の触媒有効係数 $\eta$ は 1 となるはずであ るが，結果的にこれに相当する $\eta_{0}$ が $\eta$ と異なって 0.29 の值を 示した理由を本研究では確定できなかったが，想定として， $\mathrm{SAC}$ 充填体積が有効に利用されず固定層内流路がショートス ルーしていたか，触媒カラムの中の偏流や原料セロビオース 液を事前に昇温していないため触媒カラムの入口付近で反応 水溶液温度が低下していたことが挙げられる。 $\eta_{0}$ を 0.29 と設 定した場合に $4000 \mathrm{~h}$ の経過時間 $t$ にわたり計算值と実測值は よく整合していることから，上述の課題含みであるがモデル の有用性を検証できたといえる。さらに本試験運転の初期段 階は，機械的トラブルで供給流量が急変動し，その結果 $\theta$ が 影響を受けてグルコース収率が急激に変動したが，この場合 においても計算值と試験值が一致していたことが分かる。

\section{5 流通反応器でのカーボン系固体酸触媒反応モデルの検 証}

実用のSAC流通反応器を設計する場合，3.4項で用いた粉末 状の触媒粒子では充填層を実現することが難しいため，ぺ レット(円柱)形状などに成型する必要がある。ここでは，円

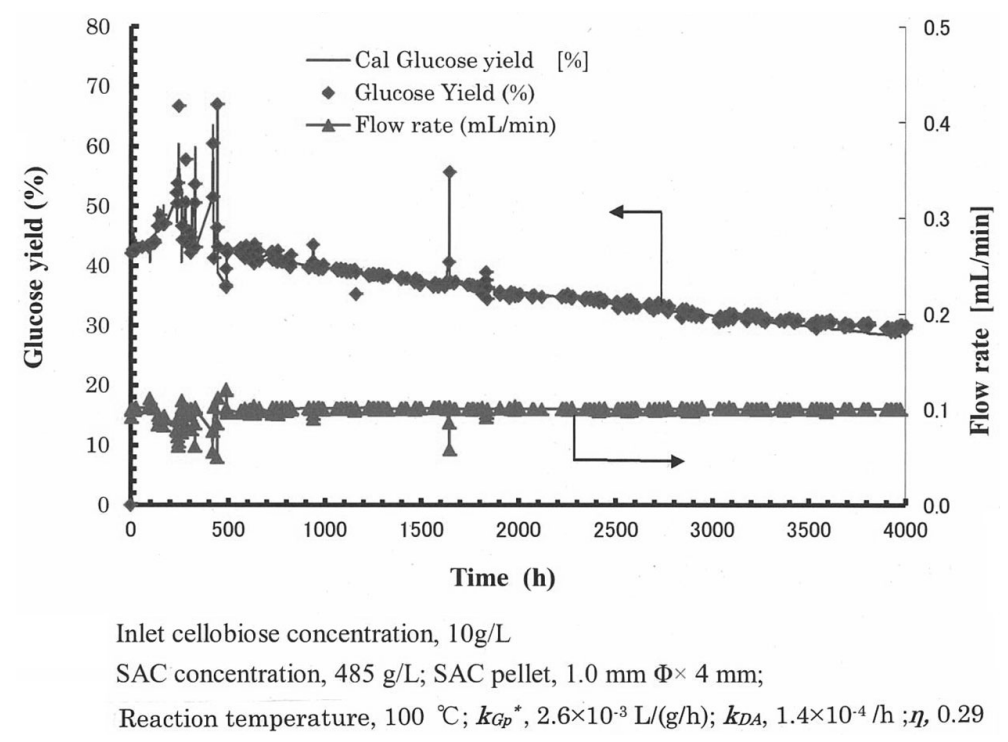

Fig. 6 Plug flow experimental result of glucose yield by SAC reaction at $100^{\circ} \mathrm{C}$ 


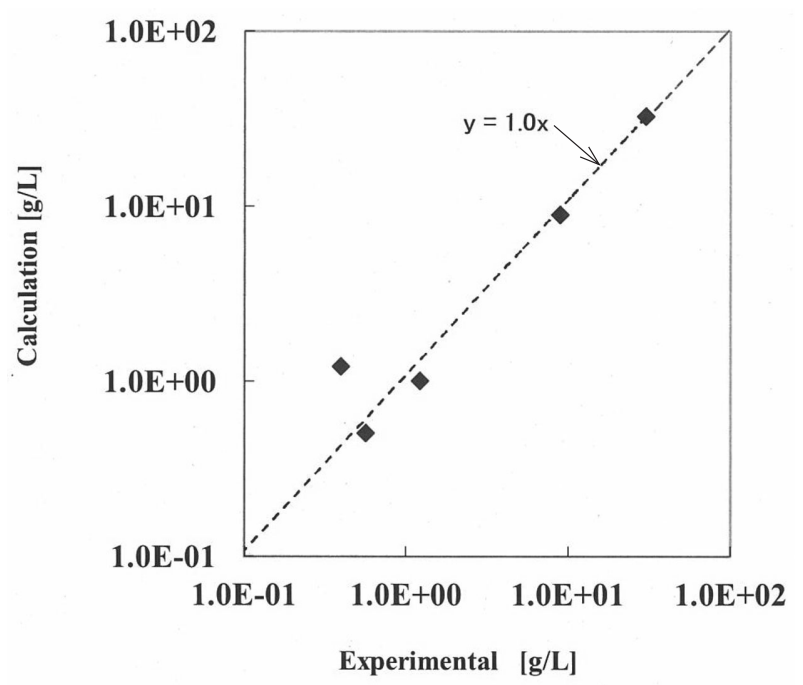

Fig. 7 Validation of the calculation values for experimental data

断面直径 $1 \mathrm{~mm} \times$ 高さ $4 \mathrm{~mm}$ の円柱の SAC 触媒を使用して 反応モデルの検証を行った。円柱状 (直径 $b \times$ 高さ $h$ ) 触媒の 球状触媒相当直径 $d_{p}$ は, 側面のみに触媒活性があるとすれば $b=(2 / 3) d_{p}$ となるため, $\phi$ が 0.3 となり $\eta$ は 0.9 程度になる ことからほぼ反応速度支配であるといえる。

実際のエンジニアリングにおいて反応モデル式(9)が広い範 囲で適用できるかの性能検証を必要とする。この反応モデル は, 変数として流量変化にともなう $\operatorname{HRT}(\theta)$ の変化と, 入口 である原料セロビオース濃度 $C_{C 0}$ を変動要素として含んでい る。これら両変動要素がSAC触媒反応速度にも影響を与える 結果, 出口グルコース濃度 $C_{G}$ が結果として変動することにな る。入口セロビオース濃度 Co が 50 から $120 \mathrm{~g} / \mathrm{L}$ と高濃度で さらにHRT が1から $4 \mathrm{~h}$ のように設定した理由は, セロビ オース濃度の 1 次式が成立するかを検証するため, セロビ オースからグルコースへの収率が 100\%にならない高い負荷 条件を選定したためである。その結果 (Fig. 7) 出口グルコー ス濃度の試験值と計算值がほぼ一致していたことから，これ らの反応条件下においても流通反応器でのSAC反応速度モデ ルを検証でき，その適用性を確認した。

\section{4. 結 言}

セロビオースからグルコースを生成するセロビオース糖化 反応について, 反応速度モデルを用いて生体触媒である酵素 $\beta$-グルコシダーゼ (BGL) と化学触媒であるカーボン系固体 酸触媒 $(\mathrm{SAC})$ による比較を行った。それぞれの加水分解反応 速度の特徵から, 反応速度向上のためにはBGLでは既往の研 究で指摘されている通り, 生成するグルコース濃度阻害の軽 減が必要である。SACの場合は一次反応速度式で表現できる ことが分かったが, 充填層用のSAC触媒設計において有効係 数の決定に解決課題を残した。SACを用いた流通式固体触媒 酸反応の約 $4000 \mathrm{~h} に わ た る$ 経時性能試験確認を行い, セロビ オースからの高濃度SAC反応による加水分解速度モデルの検 証を行った。その結果触媒性能は徐々に低下するが長期にわ

たり一定の触媒活性を維持した。SAC は固定槽流通反応器で 使用することで流出の心配はなくなる。また, 化学触媒の特 性から, BGLとは異なり生成グルコースの濃度阻害を受けな い特徵を有することが理解できた。この成果が化学触媒を用 いた糖化技術の一つの進歩として, SAC 実用化の一助になれ ば幸いである。

\section{Nomenclature}

A

a

$b$

$C_{C}$

$C_{G}$

$\mathrm{CoO}_{0}$

D

$D_{\text {eA }}$

$d_{p}$

g

h

$k_{L}$

$K_{m}$

$K_{2 G}, K_{2 C}$

$k_{G p}$

$k_{G D}{ }^{*}$

$k_{D A}$

$t$

$W_{A}$

$Y_{G}$
SAC concentration [g/L]

SAC surface area per unit volume $\left[\mathrm{m}^{2} / \mathrm{m}^{3}\right]$

SAC pellet diameter $[\mathrm{m}]$

cellobiose concentration $[\mathrm{g} / \mathrm{L}]$

glucose concentration $[\mathrm{g} / \mathrm{L}]$

initial cellobiose concentration $[\mathrm{g} / \mathrm{L}]$

diffusion coefficient $\left[\mathrm{m}^{2} / \mathrm{h}\right]$

effective diffusion coefficient $\left[\mathrm{m}^{2} / \mathrm{h}\right]$

spherical diameter of SAC $[\mathrm{m}]$

gravitation acceleration $\left[\mathrm{m} / \mathrm{s}^{2}\right]$

pellet height [m]

mass transfer constant of liquid film $[\mathrm{m} / \mathrm{h}]$

Michaelis constant of BGL-hydrolysis reaction [g/L]

inhibition constant of BGL by glucose and cellobiose,

respectively $[\mathrm{g} / \mathrm{L}]$

reaction rate constant of glucose production $[1 / \mathrm{h}]$

reaction rate constant of glucose production per SAC

concentration $[\mathrm{L} / \mathrm{g} / \mathrm{h}]$

reaction rate constant of SAC deactivation $[1 / \mathrm{h}]$

reaction time $[\mathrm{h}]$

flux of cellobiose per particle outer surface area [g/ $\left.\mathrm{m}^{2} \mathrm{~h}\right]$

glucose yield [\%]

\author{
$<$ Greek symbol> \\ porosity [-] \\ SAC effectiveness factor [-] \\ fitting parameter [-] \\ hydraulic retention time $[\mathrm{h}]$ \\ specific BGL-hydrolysis reaction rate $[\mathrm{g} / \mathrm{L} / \mathrm{h}]$
}

maximum specific BGL-hydrolysis reaction rate $[\mathrm{g} / \mathrm{L} / \mathrm{h}]$ apparent density of SAC particle in water $[\mathrm{g} / \mathrm{L}]$

tortuosity factor [-]

Thiele module [-]

\section{文 献: References}

1) Cherry, J. R., FENG X., 高木忍, バイオサイエンスとイン ダストリー, 63(7), 451 (2005) : Cherry, J. R., Feng X., Takagi, S., Bioscience and bioengineering, 63 (7), 451 (2005)

2) Rahman, Z., Shida, Y., Frukawa, T., Suzuki., Y., Okada., H, Ogasawara., W., Morikawa, Y., Biosci. Biotechnol. Biochem., 73 (5), 1083(2009) 
3）小林良則, BIO INDUSTRY, 27 (11), 13(2010)：Kobayashi, Y., BIO INDUSTRY, 27 (11), 13(2010)

4) Kitano, M., Tamaguchi, D., Suganuma, S, Nakajima, K., Kato, H., Hayashi, S., Hara, M., Langmuir, 26 (9), 5068(2009)

5) Suganuma, S., Nakajima, K., Kitano, M., Yamaguchi, D., Kato, H., Hayashi, S., Hara, M., Solid State Science, 12, 1029 (2010)

6) Kitano, M, Sato., K, Nariai, K, Kaneko, N., Hara, M., Jornal of Chemical Engeering of Japan, Submitted
7）成相健太郎，金子典充，佐藤建治，北野誠，原亨和，第 7 回バイオマス科学会議 発表講演集，18(2012)：Nariai, K., Kaneko, N., Sato, K., Kitano, M., Hara, M., 7th Biomass Kagaku-Kaiki of Japan, 18(2012)

8) Philippidis, G. P., Smith T. K., Whyman, Biotechnology and bioengineering, 41, 864(1993)

9）橋本健治, 反応工学, (培風館) : Hashimoto, K., Chemical Reaction Engineering, (Baifukan) 